\title{
Peningkatan Pemahaman Peserta Didik Kelas VII Melalui Metode Inside Outside Circle dengan Bantuan Media Video Animasi
}

\author{
Aziz Kurniawan \\ Institut Agama Islam Negeri (IAIN) Purwokerto \\ azizkurniawan@iainpurwokerto.ac.id
}

\begin{abstract}
Abstrak: Penelitian yang dilakukan memiliki tujuan yaitu memberikan peningkatan kepada peserta didik melalui metode Inside Outside Circle dengan bantuan media video animasi. Metode inside outside circle melatih peserta didik untuk meningkatkan pemahaman dalam pembelajaran karena proses pembelajaran peserta didik saling bertukar informasi dengan yang lain. Hasil dari penelitian ini menunjukan bahwa pembelajaran yang menerapkan inside outside circe dengan bantuan video animasi memberikan konstribusi bagi peserta didik untuk meningkatkan pemahaman dalam suatu pembelajaran. Diketahui bahwa sebelum proses pembelajaran rata-rata pretest pada kelas yang eksperimen sebesar 38,055. Sedangkan kelas kontrol sebesar 42,167. Setelah treatment dilaksanakan terjadi peningkatan bahwa rata-rata posttest pada kelas yang eksperimen sebesar 63,43. Sedangkan kelas kontrol sebesar 53,46. Hasil peningkatan tersebut diukur melalui uji-t yang kemudian ditarik kesimpulan bahwa nilai $t_{\text {hitung }}>t_{\text {tabel }}$ dengan nilai 4,24 >1,99 yang menjelaskan pemahaman peserta didik dengan menggunakan model Inside Outside Circle bantuan media animasi video lebih baik daripada pembelajaran konvensional
\end{abstract}

Kata Kunci : Pemahaman Peserta Didik; Inside Outside Circle; Video Animasi

Abstract: The research conducted has a purpose is to provide improvement to students through the Inside Outside Circle method with the help of media video animation. The inside outside circle method trains students to increase their understanding of learning because the learners ' learning process exchanges information between each other. The results of this study showed that the learning that applied inside outside Circe with the help of animated video gave the contribution for students to improve understanding in learning. It is noted that before the average learning process pretests in the experimental class was 38.055. The control class is 42.167. After the treatment, there was an increase that the average posttest of the experimental class was 63.43. The control class is 53.46. The result of the increase was measured through test-t which was then concluded that the value of Thitung > this with a value of $4.24>1.99$ that explains the understanding of learners using the Inside Outside Circle model of video animation media help better than conventional learning

Keywords: Learners understanding; Inside Outside Circle; Video Animation. 


\section{Pendahuluan}

Kurikukum 2013 merupakan kurikulum yang memiliki tujuan dalam mempersiapkan peserta didik yang memiliki karakter beriman kepada Tuhan Yang Maha Esa, produktif, kreatif serta inovatif yang mampu memiliki daya saing dalam berkehidupan era globalisasi. Peserta didik dalam proses pembelajaran memiliki tuntutan yang tinggi salah satunya mampu berpikir kreatif, inovatif serta berkarakter. Maka dalam implementasinya tujuan dari kurikulum 2013 memiliki empat kompetensi inti yang tercantum dalam Permendikbud No 69 Tahun 2013 yaitu 1) kompetensi spiritual, 2) kompetensi sosial, 3) kompetensi pengetahuan dan 4) kompetensi ketrampilan.

IPA merupakan salah satu mata pelajaran yang menekankan pada proses ketrampilan yang sesuai dengan tujuan dari kurikulum 2013 yang nantinya diharapkan peserta didik mampu memiliki daya saing dalam menghadapi era globalisasi. Namun dalam kenyatannya peserta memiliki beberapa kendala yang harus diperhatikan oleh guru. Salah satunya pemahaman pengetahuan peserta didik terhadap suatu materi yang cenderung rendah yang berakibat pada hasil belajarnya.

Menyikapi hal tersebut peran guru dalam proses pembelajaran merupakan kunci utama keberhasilan dalam belajar. Namun dalam kenyataanya metode yang digunakan guru hanya mengunakan metode pengajaran yang bersifat konvensional dimana guru menjadi pusat perhatian peserta didik (teacher center) tanpa mengunakan media bantu dalam menerangkan yang mengakibatkan pemahaman peserta didik menjadi antar satu dengan yang lain memiliki perbedaan yang besar. Selain itu, penerapan model pembelajaran yang inovatif perlu dilakukan sebagai cara guru dalam menstransfer ilmu secara keseluruhan tanpa kendala. Salah satu model pembelajaran yang cocok diterapkan menurut peneliti yaitu model pembelajaran inside outside circle dimana model pembelajran tersebut menuntut peserta didik agar menjadi lebih semangat dalam belajar dikarenakan peserta didik menjadi pelaku dalam pembelajaran langsung. Menurut Ningsih dan Susi (2017) menjelaskan model pembelajaran Inside Outsede Circle merupakan model pembelajaran yang memberikan ruang kepada peserta didik untuk bertukar informasi dengan teman sebayanya sehingga meningkatkan pemahaman peserta didik dalam belajar. Implementasi dalam penerapan model tersebut memiliki pemgaruh yang sangat besar terutama dalam hal berkolaborasi dengan peserta didik lain yang tentunya menumbuhkan motivasi bagi peserta didik dan menjadi tertantang dalam belajar (Hartini, Tika Puji. dkk : 2018)

Berdasarkan hasil wawancara dengan salah satu guru di SMP Empu Tantular yaitu Ibu Suwartiningsih yang mengampu IPA kelas VII menjelaskan bahwa pemahaman peserta didik masih jauh kurang hal tersebut dibuktikan dari tes harian yang dilaksanakan masih banyak peserta didik yang mendapatkan nilai di bawah KKM $67 \%$ melihat kenyataan tersebut perlunya permasalahan tersebut diselesaikan dengan adanya perubahan pada cara mengajar yaitu dengan menggunakan media animasi video yang diharapkan peserta didik memudahkan memahami suatu pelajaran juga menumbuhkan semangat akan belajar. Dari video yang diangkat peneliti yaitu video tentang materi perncemaran lingkungan.

Menurut Alannasir (2016) menjelaskan bahwa media belajar yang tepat mampu meningkatkan semangat belajar untuk peserta didik yang diharapkan mampu meningkatkan pemahaman peserta didik. Hal tersebut sejalan dengan hasil penelitian Yuliani (2017) pengaruh media animasi dalam pembelajaran mampu meningkatkan 
pemahaman konsep mahasiswa Pendidikan fisika. Sehingga pada penelitian ini peneliti memiliki tujuan yaitu 1) meningkatkan pemahaman peserta didik dalam materi pencemaran lingkungan; 2) peserta menjadi aktif dalam pembelajaran

\section{Metode Penelitian}

Metode penelitian yang diterapkan oleh peneliti yaitu dengan menentapkan metode kuantitatif dimana desain penelitian dengan True Eksperimen dengan PretestPosttest Control Grup Desaign denga tujuan agar peneliti mampu mengetahui sejauh mana pemahaman peserta didik baik sebelum pembelajaran maupun sesudah pembelajaran. Pada penelitian ini menggunakan dua kelas sebagai pembanding dimana satu kelas sebagai kelas kontrol dan satunya sebagai kelas eksperimen. Populasi penelitian ini yaitu peserta didik di SMP Empu Tantular kelas VII tahun ajaran 2017/2018. Pengambilan sampel pada penelitian ini dengan menggunakan Teknik purposive sampling dengan pertimbangan pengamatan pemahaman peserta didik yang telah diamati oleh peneliti sehingga diperoleh pada penelitian ini yaitu siswa kelas VII Semester genap dimana kelas VII A sebagai kelas kontrol dan kelas VII C sebagai kelas eksperimen.

Teknik yang digunakan peneliti dalam pengambilan data dalam penelitian ini yaitu dengan metode tes dimana tes tersebut digunakan untuk melihat pemahaman peserta didik materi pencemaran lingkungan. Metode tes yang digunakan yaitu dengan tes pretest dan posttest. Dimana pada metode tes nantinya digunakan dalam perhitungan uji-t untuk melihat hasil peningkatan pemahaman peserta didik

\section{Hasil dan Pembahasan Hasil}

Data pertama yang diperoleh dari penelitian ini yaitu data pretest yang dilaksanakan sebelum treatment dilakukan diperoleh data ditampilkan dalam bentuk tabel 1 sebagai berikut :

Tabel 1 Pretest sebelum treatment dilaksanakan

\begin{tabular}{lll}
\hline \multirow{3}{*}{ Sumber Variasi } & Kelas & Kelas \\
& Kontrol & Eksperimen \\
\cline { 2 - 3 } & Pretest & Pretest \\
\hline Rata-rata & 42,167 & 38,055 \\
Varians & 174,154 & 162,3 \\
Standar deviasi & 13.196 & 12,73 \\
& & \\
\hline
\end{tabular}

Data yang ditampilkan pada Tabel 1 menjelaskan hasil pretest pada kelas yang eksperimen memiliki rata-rata sebesar 38,055. Sedangkan pada kelas kontrol sebesar 42,167 yang artinya pada kelas kontrol jauh memiliki rata-rata pretest yang besar dikarenakan kelas kontrol terkenal dengan kelas yang rata-rata memiliki kemampuan lebih baik daripada kelas eksperimen.

Setelah pembelajaran selesai dilaksanakan atau treatment selesai dilakukan, langkah selanjutnya peneliti melalukua ujian posttest dengan tujuan untuk melihat ada 
atau tidaknya peningkatan pada kelas yang dikenai treatment tersebut. Hasil posttest dapat dilihat melalui tabel 2 sebagai berikut:

Tabel 2. Hasil Posttest setelah treatment terlaksana

\begin{tabular}{lll}
\hline \multirow{2}{*}{$\begin{array}{l}\text { Sumber } \\
\text { Variasi }\end{array}$} & Kelas & Kelas \\
& Kontrol & Eksperimen \\
\cline { 2 - 3 } & Posttest & Posttest \\
\hline Rata-rata & 53,46 & 63,43 \\
Varians & 107,65 & 109,86 \\
Standar deviasi & 10,37 & 10,48 \\
\hline
\end{tabular}

Berdasarkan hasil yang tertera pada Tabel 2 menjelaskan bahwa setelah dilakukan treatment terdapat peningkatan yang signifikan pada kelas eksperimen yang mula-mula memiliki rata-rata pretest sebesar 38,055 mengalami peningkatan yang signifikan dengan rata-rata posttest setelah dilaksanakan treatment sebesar 63,43. Sedangkan pada kelas kontrol juga mengalami kenaikan namun tidak terlalu signifikan. Berdasarkan tabel 1 menjelaskan bahwa kelas kontrol saat awal pretest memiliki rata-rata yang lebih besar daripada kelas eksperimen. Hasil pretest kelas kontrol dengan rata-rata 42,167 pada tabel 2 rata-rata sebesar 53,46.

Langkah selanjutnya peneliti melakukan uji-t dimana tujuan dari dilakukan uji tersebut untuk melihat perbedaaan pemahaman peserta didik pada kelas eksperimen dengan kelas kontrol.

Tabel 3. Hasil Perhitungan Uji t-test pada posttest

\begin{tabular}{lll}
\hline \multirow{2}{*}{ Variasi } & \multicolumn{2}{c}{ Posttest } \\
\cline { 2 - 3 } & Kontrol & Eksperimen \\
\hline Rata-rata & 53,46 & 63,43 \\
$\mathrm{DK}$ & 37 & 37 \\
$\mathrm{t}_{\text {hitung }}$ & 4,24 & \\
$\mathrm{t}_{\text {tabel }}$ & 1,99 & \\
Kriteria & $\mathrm{H}_{0}$ ditolak \\
& $\mathrm{t}_{\text {hitung }}>\mathrm{t}_{\text {tabel }}$ \\
\hline
\end{tabular}

Hasil uji-t menjelaskan bahwa nilai $t_{\text {hitung }}>\mathrm{t}_{\text {tabel }}$ dengan nilai 4,24 > 1,99 yang berarti menjelaskan bahwa pemahaman peserta didik dengan menggunakan model Inside Outside Circle dengan bantuan media animasi video lebih baik daripada pembelajaran konvensional.

\section{Pembahasan}

Hasil dari penelitian menjelaskan bahwa model pembelajaran Inside Outside Circle mampu meningkatkan pemahaman peserta didik. Hal tersebut dibuktikan dari hasil $u j i-t$ yang diperoleh dari penelitian yaitu sebesar nilai $t_{\text {hitung }}>t_{\text {tabel }}$ dengan nilai 4,24 > 
1,99. Hal tersebut terjadi karena peran peserta didik dalam belajar menjadi terlibat langsung. Dalam pembelajaran peneliti juga menggunakan alat bantu berupa video animasi yang diberikan sebelum model pembelajaran Inside Ouside Circle diterapkan.

Pada awal pembelajaran peserta didik di sajikan sebuah video animasi. Setelah video animasi selesai diputar peserta didik diminta untuk membentuk dua kelompok. Dimana masing-masing dari kelompok membentuk sebuah lingkaran, satu lingkaran menghadap kedalam sedangkan satunya mengahadap keluar. Nantinya setiap peserta didik saling bertukar informasi sesuai pemahaman mereka dalam mengamati video yang sidah ditayangakan diawal pembelajaran.

Hasil dari penelitian ini sesuai dengan hasil penelitian terdahulu yaitu Wahyudi dan Lilis (2017) yang menjelaskan bahwa model pembelajaran ini merupakan model pembelajaran yang inovatif yang melatih peserta didik dalam mengembangkan kreatifitasnya. Purwaningrum dkk (2017) proses belajar dengan Inside Outside Circle melatih ketarampilan sosial peserta didik agar mampu mengkomunikasikan hasil pemikirannya yang natinya dapat meningkatkan hasil belajar yang akan dicapainya. Sedangkan menurut Megawati dkk (2014) dari hasil penelitiannya menujukan bahwa terdapat hasil yang berbeda antara peserta didik yang memperoleh pembelajaran dengan model Inside Outside Circle dengan peserta didik yang memperoleh model pembelajaran konvensional dengan dibuktikan besar nilai $t_{\text {hitung }}$ sebesar 14,49 sedangkan nilai $t_{\text {tabel }}$ sebesar 2,007. Apsari, dkk (2018) menerangkan dengan menggunakan model pembelajaran Inside Outside Circe memberikan keefektifan untuk peningkatan hasil belajar dengan bukti terdapat $80 \%$ peserta didik telah memenuhi ketuntasan hasil belajar.

Faktor lain peningkatan keberhasialan pemahaman peserta didik selain penggunaan model pembelajaran Inside Outside Circle yang mampu meningkatkan pemahaman peserta didik media animasi video ternyata memiliki pengaruh terhadap keberhasilan pembelajaran hal tersebut didukung oleh hasil penelitian dari Imamah (2012) bahwa dengan penggunaan media animasi video bias menjadikan sebuah alternatif dalam pembelajaran sehingga pembelajaran dapat berhasil. Begitu juga hasil dari research Sudiarta dan Sadra (2016) yang menjelaskan bahwa penggunaan media animasi membantu guru dalam melakukan proses pembelajaran. Penggunaan media animasi video tentunya memiliki bebrapa keuntungan seperi yang dijelaskan oleh Yusuf, dkk (2017) dengan penggunaan media animasi guru memiliki keuntungan yaitu 1) peserta lebih mudah dalam memahaami suatu permasalahan; 2) materi dalam suatu pembelajaran menjadi lebih ringkas; 3) adanya inovasi dalam proses belajar dll.

\section{Kesimpulan dan Saran}

Berdasarkan hasil yang diperoleh maka peneliti dapat menarik kesimpulan yang nantiya bisa digunakan bagi peneliti lain atau sebagai bahan rujukan untuk penelitian selanjutnya. Bahwa diperoleh data dengan penggunaan model pembelajaran Inside Outside Circle mempu memberikan peningkatan pemahaman kepada peserta didik agar dalam proses pembelajaran dapat berjalan dengan baik, selain intu dengan penggunaan model pembelajaran tersebut peserta didik mampu meningkatkan skill bertukar pendapat dengan peserta didik lainnya yang nantinya pendapat tersebut mampu untuk terus dikembangkan.

Media animasi video merupakan salahsatu alternative agar guru dapat menstransformasikan pengetahuan serta dapat membangkitkan rasa ingin tahu peserta didik dalam belajar. Adapun saran yang dapat disampaikan kepada praktisi pendidikan 
atau peneliti lainnya yaitu : guru hendaknya lebih mengasah kemampuan dalam berinovasi penggunaan model pembelajaran yang menyenangkan bagi peserta didik agar peserta didik menjadi bersemangat dalam belajar. peserta didik dalam proses belajar hendaknya terus dilibatkan dalam pembelajaran yang menyenangkan sehingga dalam pembelajaran peserta didik mampu meningkatkan skill bertukar pendapat dengan peserta didik lain serta memperoleh pengetahuan baru melalui pengalaman belajarnya

\section{Daftar Pustaka}

Apsari, Mariska Windi; dkk. 2019. Keefektifan Model Pembelajaran Inside Outside Circle Terhadap Hasil Belajar Matematika Siswa kelas V SDN Panggang O1 Jepara Tahun Ajaran 2017/2018. Prosiding Seminar Nasional Pendidikan (SENDIKA) : 31-38 from http://prosiding.upgris.ac.id/index.php/SD2018/SSND2018/paper/view/2507/2510

Alannasir, Wahyullah. 2016. Pengaruh Penggunaan Media Animasi dalam Pembelajaran IPS Terhadap Motivasi Belajar Siswa Kelas IV SD Negeri Mannuriki. Jurnal of Educational Science and Technology 2(2): 81-90 from https://doi.org/10.26858/est.v2i2

Hartini, Tika Puji. Dkk 2017. Implementation of Cooperative Learning InsideOutside Circle Model to Improve Elementary School Students' Motivation and Learning Outcome. Proceedings of the 1st International Conference on Education Innovation (ICEI 2017). From https://doi.org/10.2991/icei-17.2018.87

Imamah, N. 2012. Peningkatan Hasil Belajar IPA Melalui Pembelajaran Kooperatif Berbasis Konstruktivisme Dipadukan dengan Video Animasi Materi Sistem Kehidupan Tumbuhan. Jurnal Pendidikan IPA Indonesia 1 (1) : 32-36 from DOI: $\underline{\text { https://doi.org/10.15294/jpii.v1i1 }}$

Indriarti. 2012. Meningkatkan Hasil Belajar Ipa Konsep Cahaya Memalui Pembelajaran Science-Edutaiment Berbantuan Media Animasi. Jurnal Pendidikan IPA Indonesia 1 (2): 192-197 from DOI: https://doi.org/10.15294/jpii.v1i2

Megawati, Kd. Dkk. 2014. Pengaruh Model Pembelajaran Kooperatif Tipe Inside Outside Circle (IOC) Terhadap Hasil Belajar IPA Siswa Kelas V Tahun Pelajaran 2013/2014 di Gugus VII Kecamatan Sawan. Mimbar PGSD Undiksha 2(1) from DOI: http://dx.doi.org/10.23887/jipgsd.v2i1

Ningsih, Sri Yunita dan Susi Andriani. 2017. Penerapan Model Pembelajaran Inside Outside Circle Terhadap Kemampuan Pemahaman Konsep Siswa. Journal of Mathematics Education and Science 2(2): 88-94 from DOI: https://doi.org/10.30743/mes.v2i2

Purwaningrum, Merinta Diah; dkk (2017). The Implimentation of Cooperative Learning Model Quiz-Quiz Trade and Inside-Outside Circle to Improve the Students' Social 
Skills and Learning Outcomes. International Journal of Academic Research in Business and Social Sciences 7(6): 473- 486 from DOI: 10.6007/IJARBSS/v7-i6/3005

Sudiarta, I Gusti Putu; I Wayan Sadra. 2016. Pengaruh Model Blended Learning Berbantuan Video AnimasiTerhadapKemampuan Pemecahan Masalah dan Pemahaman Konsep

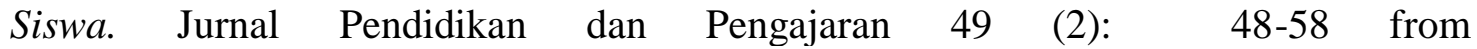
DOI: http://dx.doi.org/10.23887/jppundiksha.v49i2

Wahyudi, Dedi dan Lilis Marwiyanti. 2017. Penerapan Model Pembelajaran Inside Outside Circle dalam Mata Pelajaran Akidah Ahlak. Jurnal Mudarrisuna 7(2): 267-292 from DOI: http://dx.doi.org/10.22373/jm.v7i2.2369

Yuliani, Hadma. 2017. Pembelajaran FisikaMenggunakan Media Animasi Macro Media Flash-MX dan Gambar untuk Meningkatkan Pemahaman Konsep Mahasiswa. Jurnal Ilmiah Pendidikan Fisika Al-Biruni 6(1): 13-21 from DOI: 10.24042/jpifalbiruni.v6i1.596

Yusuf, Muhammad Mustofa. Dkk. 2017. Developing of Instructional Media-Based Animation Video on Enzyme and Metabolism Material in Senior High School. Indonesian Journal of Biology Education 3(3): 254-257from DOI: https://doi.org/10.22219/jpbi.v3i3.4744 